\title{
Communication and Transition of Self-Identity of Ex-Prostituted Women to Residents of Rehabilitation Institutions
}

\author{
Syaiful Rohim \\ Communication Studies, Political and Social Science Faculty \\ Muhammadiyah Prof. Dr Hamka University Jakarta \\ Limau II Street, Kebayoran Baru, Jakarta Selatan, 12130, Indonesia \\ Corresponding author: syaiful_rohim@uhamka.ac.id \\ Phone: 08159349713
}

\begin{abstract}
The arrest and the process of guidance rehabilitation activities for ex-prostitution make them and their identities become different before undergoing the arrest and guidance process. These are that maybe felt by all exprostitution in rehabilitation. The purpose of this study was to explore the phenomenon of communication in the rehabilitation program as well as the changes of identity and self of ex-prostitution after experiencing an arrest by the law enforcement officers or Civil service police Unit (Satpol PP) and the rehabilitation program in rehab place. This research method was using qualitative approach as an analysis in this research activities, by tracing the changes in self-concept or psychological changing and consciousness which is experienced by an Ex-prostitute women after being caught in a "raid" operation and put into a rehabilitation center. The results of this study reveal that ex-prostitutes or other nicknames that they usually called slut before being caught, had a concept and awareness of themselves as someone who has a typology of work as Professional, Semi-Professional and Amateur prostitutes according to their background and their reasons for choosing to be prostitutes. After the arresting and guidance in the rehabilitation center, make the subject reformulate his physical, psychological and social existence as a new identity, including physical appearance, attitude and social orientation. This research gives contribution in the form of recommendations for policy-making and the process of guidance for ex-prostitutes, so it can make easier communication and the effectiveness of guidance because it sees from the aspect of awareness and identity as objects and subjects in the rehabilitation process. Keywords: Communication; Identity Transition; Self-Awareness of Ex-Prostitute; Rehabilitation Center; Qualitative Research
\end{abstract}

\begin{abstract}
Abstrak
Penangkapan dan proses pembinaan dalam kegiatan rehabilitasi bagi eks-PSK (Pekerja Seks Komersial) menjadikan diri dan identitasnya yang berbeda sebelum menjalani proses penangkapan dan pembinaan tersebut. Demikian halnya yang mungkin dirasakan oleh para eks-PSK yang menjalani di panti rehabilitasi. Tujuan penelitian ini untuk menelusuri fenomena komunikasi dalam program rehabilitasi serta perubahan identitas dan diri eks-PSK setelah mengalami peristiwa penangkapan oleh petugas penertiban atau Satuan Polisi Pamong Praja (Satpol PP) dan program rehabilitasi di dalam panti. Metode penelitian ini menggunakan Pendekatan kualitatif sebagai alat analisis dalam kegiatan penelitian ini, dengan menelusuri perubahan konsep diri atau perubahan psikologis dan kesadaran yang dialami seorang mantan PSK setelah tertangkap dalam operasi "razia" serta dimasukkan ke dalam panti rehabilitasi Hasil penelitian ini mengungkapkan bahwa eks-PSK atau terdapat julukan lain disebut sebagai pelacur saat sebelum tertangkap memiliki konsep dan kesadaran tentang dirinya sebagai seseorang yang memiliki tipologi pekerjaan sebagai PSK Profesional, Semi Profesional dan Amatir sesuai dengan latar belakang dan alasan memilih sebagai PSK. Pasca penangkapan dan pembinaan didalam panti menjadikan subjek mereformulasi keberadaan diri secara fisik, psikis dan sosialnya sebagai identitas baru antara lain penampilan fisik, orientasi sikap dan sosialnya. Penelitian ini memberikan kontribusi berupa rekomendasi pengambilan kebijakan dan proses pembinaan bagi para eks-PSK, sehingga dapat mempermudah komunikasi dan efektifitas pembinaan karena melihat dari aspek kesadaran dan identitas sebagai objek dan subjek dalam proses rehabilitasi. Kata kunci: Komunikasi; Transisi Identitas; Kesadaran Diri Eks-PSK; Panti Rehabilitasi; Kualitatif
\end{abstract}




\section{Introduction}

Being a good person in the eyes of a human's perception and judgment is the thing most expected by humans. As a creature who always needs acknowledgment in all their interactions. As a hadith of the Prophet Muhammad SAW that the best of humans is the best for others, it means that we can be said become useful when we can give something useful for other humans. As a result of this role and benefit, a person is dubbed of his kindness.

Identity which automatically becomes part of the epithet which is given by society to us will have meaning and influence on social behavior and social activities in the social system. Moreover, the epithet will give an inherent predicate from a person. The epithet of courtesan, hooker, prostitutes are some of the names for someone's identity that refer to some women who choose to work as sellers of sexual pleasures that are traded as their work activities. People used to call them Commercial Sex Worker (PSK). Another definition of a prostitute is a woman with a problem, becoming a prostitute, namely selling herself with trafficking networks, pimps, and thugs who commit fraud, coercion, and abuse that is not visible or secretly (Hanna, 1993).

In the history of its existence, the choice of the job or profession to become a prostitute or commercial sex worker is a type of profession that is also in line with human civilization since ancient times. Prostitution is a practice that gives negative impacts on sex workers, family and community (Binahayati Rusyidi, 2018). There have been many studies on the existence of Prostitute Women in various social sciences and humanities as well as in the communication scientific tradition with a variety of approaches and methodologies. Some of the studies that have been done about the Social Rehabilitation Process. The social rehabilitation process has a function as prevention, healing, and maintenance of prostitutes to gain knowledge that can be developed in life after being sent home from the Social Institution so that they do not return to jobs that are prohibited by religion, because before they were in rehabilitation they lived in a free and free environment. Their language is often dirty and their emotions are uncontrollable. So that their existence in rehabilitation they seek sympathy from others and attention from others (Kholifah, 2019). Social Rehabilitation Process of Prostitute Women at the Palimanan Social Rehabilitation Center for Women in the Cirebon Regency says that most cases of prostitutes who have attended rehabilitation will return to prostitution (Ramadhani, W. S., Sulastri, S., \& Nurhaqim, 2017). There is also a researcher who found that The results of the research show that the process of social rehabilitation at PSKW Andam Dewi includes the guidance of personality, spirituality, and skills as a provision of a better life and useful for the assisted citizens after going out later (Angela, 2018). Thus, researchers are interested in seeing how identity transitions after obtaining or the following rehabilitation.

Other researchers also researched these themes as done by Syaiful Rohim who said that research was carried out by in-depth interview methods, observation, and documentation study as techniques in collecting data. This study shows that the self-concept of ex-prostitutes is negative before entering rehabilitation (when becoming prostitutes) based on the subject's motivation to become prostitutes, and also as a self-image due to physical, mental, and social perceptions (Rohim, 2010)

As a social problem, prostitution needs serious handling so that the increasing of a number from year to year and does not give a negative impact on people's lives. One of them is by empowering prostitutes women (PSK) through the development of life skills (Budiman, 2013). For some ex-prostitutes are given some guidance so that they can be separated from prostitution activities. The guidance is in the form of guidance to obtain psychological health, physical, social and religious guidance. 
Besides that, it is also equipped with skills guidance (Hasneli, 2016). Another researcher also showed that the management and guidance program of ex-prostituted women (WTS) at the Mattiro Decent Women's Social Service Center (PPSKW) in Makassar City went well, this can be seen from the planning, organizing, mobilizing, monitoring and working skills offered through skills in make-up, culinary, and sewing (Kartini et al., 2016). Therefore, the results of this research will certainly give more knowledge of communication which takes sub-themes and research subjects from the prostitution community or commercial sex workers.

On the other hand, the treatment and confession of the existence of these prostitutes among the community and our social system are still faced with the complexity of problems, which in various aspects, including religion, culture, and legal products, have not provided many solutions to the various complexities of the problems which are faced. As the economy, which is the basic need, must be staked, dealing diametrically with religious and cultural rules that limit the choice of profession to become a prostitute. It is a dilemma and it becomes complicated if it is to be used as decision-making because being a prostitute is a quick and short alternative to fulfill the economic needs but she has to reproduce her spirituality and identity with good bad aspects and social responses that call it deviant behavior.

They think working as a prostitute is a part of rational choice for those who are faced with the urgency of various basic needs specially to fulfill their economic it is only in their area of perception. As agreed by communication scientists, the essence of communication is perception. Then this perception is what distributes a person's self-identity so that in the end he will make decisions and communication activities in various social activities. Social life in the view of symbolic interaction means a human interaction by using a symbol that is always used by people to communicate and interact with each other. In these interactions also occur efforts to define and interpret to each other between one action with the other (Rohim, 2015).

When someone chooses in working as a commercial sex worker with all the activities that they do, it is considered contrary to social norms and rules in society. This assumption also has implications for people's perceptions of their life activities. The negative impacts which are directly or indirectly caused by the practice of prostitution are one source of justification for making prostitution a social problem, a source of immorality and crime, as well as a social disease that must be eradicated. Prostitution is seen as having various unwanted impacts on various aspects of people's lives. From the point of view of human rights of humanity, prostitution is seen as a violation of human rights and human values.

As one of researcher said that the impact caused by the presence of commercial sex workers is disturbing the community. The social reaction of the community towards commercial sex workers shows that there are community members who reject the presence of these sex workers in their midst. This is because they feel disgusted and afraid of being infected by sexually transmitted diseases that can be carried by these sex workers. Then the community members feel that the environment in which they live is tarnished because of the presence of prostitutes in their midst. Difficulty interacting with the surrounding community; because most people think that sex workers are despicable, of course sex workers will think that the people around them are hostile and ostracize them, so that sex workers are afraid to interact with the surrounding community who they think do not accept their existence in the community due to their work status (Pambudi Putra Yahya, 2018). 
Likewise, the government as the implementer and carry out the function of enforcing the law and public order is a separate problem when dealing directly with those (PSK) who are carrying out their activities and have received a negative stigma for their choice of work. One of the risks faced by these prostitutes is arrest or control by government officials through the civil service police (Satpol PP). The control is a legal step taken by the government, which is then followed up by guidance the sex workers in rehabilitation centers. With various programs carried out such as assessment of providing soft skills or life skills and religious-spiritual guidance. It is hoped that this guidance can lead them in changing their behavior and a new awareness of all sex workers (PSK). As Widya said that rehabilitation is also to provide skills for prostitutes so they don't return to prostitution (Ramadhani et al., 2017). The act of teaching in the context of changing behavior (rehabilitation) can be interpreted as an effort to provide knowledge, guidance and therapy to a patient (communicant) about everything in order to change and repair bad behavior and build a positive personality. Some of the concepts above show that rehabilitation is considered as a process of providing knowledge, guidance to patients or clients. In the context of providing knowledge, direction, and guidance, communication occupies a strategic role. Rehabilitation activities or therapists are communication activities, this is marked by the process of spreading knowledge from a psychologist or therapist (communicator) both guidance and direction to patients or clients as targets (communicants) with the aim for increasing knowledge, changing perceptions, behavior and restoring bad personality or other physical aspects in a patient or client (communicant). That is why the existence of communicator determining the success of delivering a message.

In the study of communication science, the changes of identity and self-concept are related with the intra-personal and interpersonal communication system (Rakhmat, 2011). The transformation and the changes of identity and awareness is seen and interpreted as communication behavior. Alfred Shultz calls it a social action (Kuswarno, 2009).

This is what the researcher examines how to reveal the changes and transitions of new self-identities and how the phenomenon of intrapersonal communication will certainly affect the variety or form of awareness of interpersonal communication when it has finished running the rehabilitation program. Therefore, the purpose of this study is to obtain an overview of the identity and self-awareness of research subjects before and after guidance in a rehabilitation center as a phenomenon of identity transition.

\section{Research Method}

This study used qualitative research methods, qualitative research is providing data in descriptive about the social phenomena (Cresswell, W, 1998). This approach begins with the researcher's academic activities using inductive thinking, where the researcher is required to capture various social facts through field observations. In qualitative research, the researcher will later process the information obtained in the field by describing what the researcher gets qualitatively or not in general, considering that qualitative is processing the results of interviews that are discussed in depth.

To reveal the reality of ex-prostitutes with the characteristics mentioned above, an interpretive approach is needed, because this approach provides space for each researcher to explore (extract) research data naturally or closer and longer with research subjects (emic). The closeness and longevity of the researcher with the research subjects allow the researcher to reveal the unique and hidden realities of the unique community, in this case, the subjective side of ex-prostitutes who interact in the orphanage, so that the results of this study are maximized and rich in authentic data. 
Figure 1 Research Subject Profile

\begin{tabular}{cccccccc}
\hline No & Name & Age & Status & Religion & Education & $\begin{array}{c}\text { Experience } \\
\text { as Prostitute }\end{array}$ & Reason \\
\hline 1 & An & 28 & Single & Christian & - & 4 years & Work \\
2 & Mis & 31 & Widow & Islam & High School & 2 years & Work \\
3 & Fir & 23 & Single & Islam & High School & 2 years & Trend \\
4 & Del & 22 & Single & Islam & Junior High School & 1 years & Trend \\
5 & Jel & 24 & Widow & Islam & Junior High School & 3 years & Divorce \\
6 & Ros & 30 & Married & Islam & Junior High School & 3 years & Work \\
7 & Lid & 28 & Widow & Christian & Junior High School & 5 years & Work \\
8 & Mel & 29 & Widow & Islam & Vocational School & 2 years & Divorce and Work \\
9 & Ien & 25 & Widow & Islam & Junior High School & 3 years & Trend \\
10 & Sam & 24 & Single & Islam & Primary School & 3 years & Trend \\
\hline
\end{tabular}

Source: Research result (2019)

The main data source in qualitative research is from words and actions (Moleong, 2000). This research also makes statements (expressions) and the conscious actions of prostitutes as the main data sources. This data collection technique is also commonly known as observation. In this study, non-participant observation was carried out. There are three stages in analyzing data, namely; data reduction, data presentation, and drawing conclusions and verification (Huberman, 1992). The observation technique is a field strategy that simultaneously combines document analysis, interviews with respondents and informants, participation and direct observation, and introspection (Denzin, 2000).

Besides observation, this study also uses in-depth interviews the research subjects in this research consisted of 10 ex-prostitutes in all areas of Jakarta who had been and were receiving treatment and guidance in the rehabilitation program as one of the data collection techniques. Many things can be obtained from research subjects in this way, researchers can find out the views, opinions, and feelings of former prostitutes as assisted citizens, both their views about themselves, their responses, and attitudes towards others. Researchers also use method triangulation as an effort and way to compare information, data, using different methods such as comparing data obtained from interviews with observations.

\section{Result of Research and Discussion}

\section{Rehabilitation Place and Research Subject}

The Bina Karya Wanita Social Institution "Harapan Mulya" Kedoya is a local government social institution under the DKI Jakarta Social Welfare and Mental Development Agency that deals with prostitution issues. The Bina Karya Wanita Social Institution "Harapan Mulya" Kedoya is located in the capital city of Jakarta, West Jakarta, precisely on J1. Kembangan Raya no. 3 Kedoya, West Jakarta. Bina Karya Wanita Social Home "Harapan Mulya" Kedoya was built on a land area of $24,678 \mathrm{M}^{2}$ with a building area of 5,512 $\mathrm{M}^{2}$. The communities around that place are more familiar with the orphanage as a women's prison.

The Bina Karya Wanita Social Home, "Harapan Mulya" Kedoya, is in charge of organizing socialization activities for prostitutes which include identification and assessment, guidance and training as well as distribution and further guidance. Meanwhile, the objectives to be achieved in the guidance process or rehabilitation are the built and developing the order of life and livelihoods of the people who are covered by the restoration of their sense of self-respect, confidence, willingness, and ability to carry out their social functions properly and normatively in social life. 


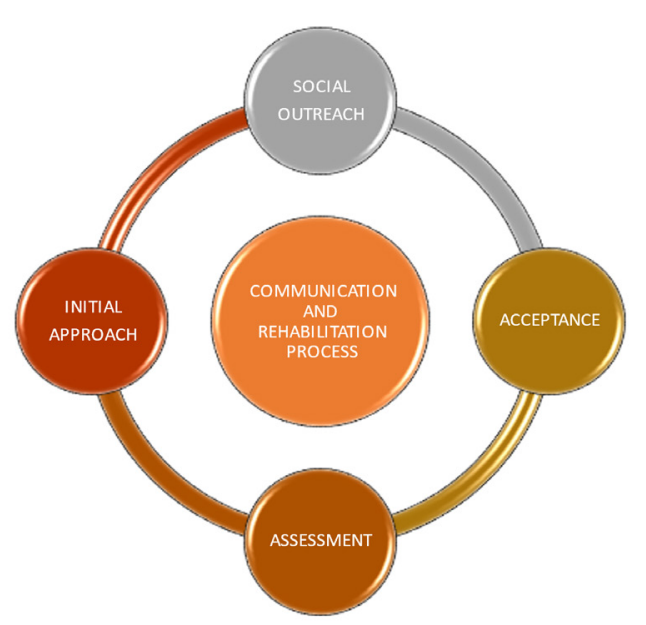

Figure 1 Communication Process in Rehabilitation in the Orphanage

Source: Adopted from observation result and interview (2019)

The research subjects in this research consisted of 10 ex-prostitutes in Jakarta who had been received treatment and guidance in the rehabilitation program, both from their religious background, status, and the reason that made themselves become prostitutes, as can be seen in the following Tabel 1 .

\section{Communication Process in Rehabilitation Program}

The communication process in guidance activities for former prostitutes in the orphanage after they become assisted citizens occurs with the form and variety of communication (Figure 1). Whether done interpersonal or structured communication when they are in various mental development program activities such as religious activities and other mental developmentmaterials.

In general, the service and rehabilitation efforts at the Bina Karya Wanita Social Home, "Harapan Mulya" Kedoya such as social outreach, initial approach, acceptance, assessment, and rehabilitation can be seen from the chart above. The term social outreach is nothing but a subtle language of the raids carried out by the local government through the civil service police unit. After raid operations were carried out on various social problems such as homeless people, beggars, prostitutes, and others, all these social problems were later referred to as the Bina Insan Bangun Daya Kedoya Social Institution or better known as prison.

After the social outreach is carried out the second step is the initial approach. This initial approach needs to be implemented because it is to find out about the former prostitutes or commonly referred to as socially assisted women. In this initial approach, former prostitutes are invited to consult personally with the officers at the orphanage, so that the officers can identify the problems experienced by the former prostitutes who will later be motivated and selected to participate in rehabilitation activities.

After the initial approach is made, the acceptance of ex-prostitutes is carried out for registration, and registration is used as data recording to obtain equipment facilities from the Woman Bina Karya Social Institution such as uniforms and other equipment for the smooth running and supporting facilities of the rehabilitation service.

Assessment is a measurement used to determine and reveal a person's psychological condition. Assessment can be in the form of interviews, observations, and interviews as well as psychological tests. After social outreach, initial approach, acceptance, and assessment are given, the next step is to provide services or rehabilitation activities for former prostitutes. The guidance and rehabilitation programs are carried out by health care provided to former prostitutes includes general examinations including general body condition such as dental examinations, blood sampling tests, stomach, and so on. The second is the material which is given includes guidance that is closely related to the problems of life in society. In addition, social guidance material includes guidance on legal awareness and health education. To assist in the social guidance, the orphanage involves social workers and officers from the community health center (PUSKESMAS) to provide education about 
health and the dangers posed by free sex. And last is providing practical skills training is a means of provision for ex-prostitutes in the hope that they have skills based on their interests and talents.

In general, the implementation of guidance program in rehabilitation activities in rehabilitation center goes as target that has been planned. However, in practice when the process of communication and interaction between the guidance or staff with ex-prostituted women as inmates, there are obstacles both technically and the essence of the communication message among the communication participants. Especially on the side of the internal perception of the subject of ex-prostituted women.

The most basic thing is the lack of intention of the inmates to turn into a normal woman in general. The changing the perception of old habits into new habits, often carried out with morning meeting activities as an effort community therapy effort, and the aim is to prepare Ex-prostitute women to understand the meaning of life by being encouraged to have a new self-awareness to be better.

Another obstacle is in terms of external factors, especially the acceptance in societies and families during the transition process and adaptation when mingling with the community. This is the crucial things to ensure the effectiveness of the program for the Ex-prostitute women, so that when the officers are re-checking, they are truly accepted by their social environment, either in the community or in their new workplace.

\section{Transition of Ex-prostitute Women Identity in The Rehabilitation Center}

An identity exists because humans need to categorize something. Therefore, social identity also involves categorizing and assigning a person to a particular social structure or social area which is larger and longer than other particular situations. Meanwhile, social identity is included in the self-categorization in groups, besides that, it is more focused on the meaning which is related to self-categorization in terms of groups, and it is more focused on the meaning related to being a member of social categories. With a greater emphasis on group identification, focusing on cognitive outcomes such as ethnocentrism, or group cohesiveness.

Social identity also serves as a reference to the existence of a person's position where he is. What level are we at, what kind of position is the same as us, and which one is different. Social identity theory sees that a social identity always clarifies itself through comparisons, but in general, the comparison is between in-groups and out-groups. In-groups are usually stereotypically positive, always better than out-groups. From the results of the analysis and the findings of the researcher after conducting interviews and observations, it was obtained a description of self-identity as a form of expression of communication behavior and the researcher continued by categorizing the identity of the Ex-prostitute women as a seconddegree construct into Professional, amateur, and semi-professional. This is obtained from the results of in-depth interviews with research subjects related to the motives of the subject's reasons for acting and choosing to become a prostitute. In general, there are 5 reasons that most demand a woman to become a prostitute, including materialism, modeling, parental support and social support, environmental factors, and economic factors (Koentjoro, 2004). Meanwhile, the cause of someone becoming a prostitute is due to heartache, economic problems, and failure in a household (Destrianti, F., \& Harnani, 2018). Another factor that makes a woman become a prostitute is to avoid the difficulties of life (Kartono, n.d.) Thus, the form of identity also becomes a part of reference as a concept that they carry and have while they are in the orphanage. The prostitutes can be classified as prostitutes professional, amateur prostitute, and semi-professional prostitutes. 
Researchers make the professional prostitutes as a classification that indicates a person makes prostitution the best way and there are no other alternative jobs. Professional prostitutes are prostitutes who consciously do this work and their family and environment are considered normal things.

As stated by Ros, one of the subjects in this study who chose to become a prostitute as a job that is usually done in her environment and even her family. "....di lingkungan gue sih banyak yang jadi WTS kayak gue. Lagian suami dan keluarga juga tahu kok. Kita ya, kerja aja" (Ros, November 23 $\left.{ }^{\text {rd }}, 2019\right)$

The pride of the family in having a lot of property and having luxurious items makes the culture of permissiveness towards all family members who work as prostitutes. Even when they are still young, they are dressed up by their parents in sexy grooming and make-up just like adults do.

Moreover, in this category, prostitution is a way that is most possible and very enjoyable as an effective way to earn money and also can satisfy their sexual desire. In this category, several subjects were found including Jel, Ien, and Lid. The activities and her choice to become a prostitute woman in the category of "professional prostitute" were also influenced by someone she referred to. In the concept of symbolic interaction, this term is called a significant other, in this case, parents, husbands, and peers or friends. In this category, research subjects are still hesitant to choose a profession outside of their activities as a prostitute because they still consider this kind of work is much easier and simpler to get a job quickly. Meanwhile, the purpose of this rehabilitation program is to give skills (Listyawati, 2020).

An amateur prostitute is the identity of a prostitute who makes prostitution due to emotional outbursts of disappointment with her family. Resentment, sadness and to fulfill the need for drugs make the incentive for a person to become a prostitute woman. In this case, it is found from the subject Mel, Mis, and Jel. "...gue mah sebenarnya gak ada niatan buat jadi WTS, tapi karena gue pernah dikecewain sama laki-laki terus gue ngobat nah buat beli obat gue gak ada duit. Jalan satu-satunya yang menurut gue gampang buat dapetin duit yah jual diri aja, deh." (Mel, December 28 $\left.8^{\text {th }}, 2019\right)$

Running the activities as a prostitute woman and satisfying the lust of men they do it not only for the main economic reason. She indeed became a prostitute as an economic demand, but the main reason that was the most dominant trigger was started from the breakdown of relationships and interactions in the family, wrong relation (the habit of getting together and visiting discos with her group of friends) so that she gradually became a drug user and ends up being a calling woman. As for the orientation of job choices in this amateur ex-prostitution typology, they are more likely to be pragmatic. They will leave the profession of prostitution if they do get a decent job and their presence in society is well accepted.

The second category is Semi-professional prostitute which is a category of prostituted women who make prostitution a continuation of the work they are doing. As the subject of Ag, who works as a massager, will be willing to serve his guests if after massaging the guest asks to serve further. Other subjects that the researchers classified in this category were An, Mis, and Mel, each of whom had a job as a Sales Promotion Girl (Waitress). Her job as a vacationing woman is a side job to increase her income. Because the choice of work as a prostitute is only as an additional or a side job, the choice and orientation of the job after undergoing the rehabilitation program in the orphanage make this Ex-prostitute women group have a positive view and will continue their main work as a choice of work which is lawful and proper and does not contrary with religious rules embraced.

The process of guiding through rehabilitation programs in the rehabilitation center has made the subjects in this study have new views and awareness, which in communication science 
is interpreted as a process of transformation or identity transition. Researchers obtained results based on interviews and observations of subjects in this study by categorizing them into three categories, namely identity transitions in physical behavior, identity transitions in psychological or psychological aspects and identity changes in social orientation.

The changes in the physical aspect are marked by the use of clothing or other accessories, such as dressing more politely, not flashy and does not seem sexy. The change looks different, because when the research subject was arrested by government officials, the research subject wore sexy clothes, accessories and used make-up and a striking perfume scent, with the aim of attracting the desires of the opposite sex.

In the psychological aspect, it can be seen that the subjects in this study fully understand that the work previously undertaken that is not in accordance with the rules, religious, cultural and society. Thus, the communication messages which is conveyed through the rehabilitation program are seen as effective activities in the distribution of information and communication from the source to the communicant. The changes in perception and behavior can be seen in the awareness of the norms and rules that exist in society. However, there are the research subjects who also understand that economic conditions, negative stigma from society are quite serious life problems. However, in this category there is a hope and self-confidence with the expertise and religious understanding gained during the rehabilitation process that will be able to support their readiness to return to society.

Working as a prostitute woman makes these ex-prostitute women close themselves because they feel unconfident and think of themselves as worthless human beings. After undergoing the process of interaction and communication in the rehabilitation center and receiving psychological assistance through religious guidance, it showed significant changes, especially in self-confidence and not having to be unconfident by preparing their readiness to mingle in the community by always carrying out worship, including praying, fasting for Muslims or services for Christians. As the subject of Mis. said: "Gue sadar kalau gue banyak dosa, makanya sekarang mah mudah-mudahan terus sih kalau udah keluar dari sini, jadi ya gue gak perlu minder masa mau niat baik Tuhan gak ngasih jalan..."(Mis, Desember 29 $9^{\text {th }}, 2019$ )

In addition to have self-confidence as the most important thing for a person to adapt to a new environment, especially for exprostitute women, it should be balanced with the ability to do relationships with other people by showing empathy and sympathy which is shown by the community in the environment where the subject will adapt and mingle as a new environment, because of the negative stigma for prostitute women will inhibit the need to socialize and will feel excluded so in psychologically they are considered as a group that is not valuable and cause low self-esteem.

In the end of the results of this study, it was found how the form of social orientation of the subjects in this study as a new form of awareness after the rehabilitation program which are typologies into the form of readiness to socialize in the community, including categories of subjects who are ready to socialize and ready to adapt. Subjects who are ready to socialize are characterized by a sense of optimism to return to society by using new skills to have a new job. The subjects who are ready to adapt are still hesitant in choosing a new job with the skills that have been taught at the rehabilitation center.

Another category as a form of social orientation of self-awareness of ex-sex workers is their ability to socialize and return to society by providing requirements, one of which is when the subject gets a decent job as a solution to the economic problems which is faced. In this category the research subjects still have doubts when they return to the community and leave their old job as a prostitute. 
"....yang namanya gaul sih khan kita biasa, kalu entar pulang kampung atau semisal balik ke rumah kalu masyarakatnya nerima dan enggak ngejek-ngejek gitu, palagi kalo dapet kerjaan yang enakan ngapain juga jadi pelacur, capek juga sih..." (Lid, Desember 22 $\left.2^{\text {nd }} 2019.\right)$

Based on the results of the limitations above, it can be interpreted and it is known that exprostitute women who have good self-confidence, good and sociable which is supported by good appearances are relatively easier and ready to do social assimilation. The research subjects who have a pessimistic assumption about their existence in society after undergoing the guidance process will be more difficult because there are doubts about the certainty of a more secure life, especially from economic problems.

\section{Conclusion}

From the explanation and research results, it is obtained a description of the self-identity and communication reality of ex-commercial sex workers while undergoing the rehabilitation process. It is obtained as a description of the existence of a transition of identity on the research subject from a collection of experiences and habits that they do before and after the rehabilitation program. The change and transition of identity are influenced by beliefs and perceptions of the Ex-prostitute women towards the choice of work to be undertaken in the future. The background and support from the people who are closest to them or the environment in which they are located also contribute to the change and transition of the identity. This was mainly found in the Ex-prostitute women group in the amateur prostitute category.

The suggestions that can be used as input for the government in dealing with social and communication problems in the process of fostering and rehabilitating Ex-prostitute women should be identified on the changes in identity and awareness of themselves, so that the handling is more humane and has a subjective perspective. Beside that the society where the community or a person, starts from the environment where are they come, and when an Ex-prostitute women come back to their communities or their environment, it is needed an open achievement and do not give a stigma or label which can change the awareness and negative perception. These things can cause a problem in the process of returning to society.

For further research, it can be done by using other approaches, such as communication ethnography or measuring the effectiveness of coaching programs in rehabilitation center for ex-prostitutes through research which is using quantitative approach methods or survey analysis.

\section{References}

Angela, D. M. (2018). Rehabilitasi Sosial Di Panti Sosial Karya Wanita Andam Dewi Sukarami Kabupaten Solok. Journal of Civic Education, 1(1), 73-80. https://doi. org/10.24036/jce.vli1.13

Binahayati Rusyidi, N. N. (2018). Penanganan Pekerja Seks Komersial di Indonesia. Prosiding Penelitian \& Pengabdian Kepada Masyarakat, 5 no.3, 303-313.

Budiman, M. A. (2013). Pemberdayaan Wanita Tuna Susila (Wts) Melalui Kecakapan Hidup (Life Skill) Keterampilan Salon Tata Kecantikan Rambut (Studi Kasus Di Resosialisasi Argorejo Sunan Kuning Kota Semarang). Journal of Nonformal Education and Community Empowerment, 2(2), 61-67. https:// journal.unnes.ac.id/sju/index.php/jnfc/article/view/2268/2083

Cresswell, W, J. (1998). Qualitative Inquiry and Research Design Choosing Among Five Traditions. Sage Publications, Inc.

Denzin, N. K. \& Y. S. L. (2000). Handook of Qualitative Research. Sage Publications, Inc.

Destrianti, F., \& Harnani, Y. (2018). Studi kualitatif Pekerja Seks Komersial (PSK) di Daerah Jondul Kota Pekanbaru Tahun 2016. Jurnal Endurance, 3 (2), 302. 
Hanna F. (1993). Dari Singkawang ke Sampit Kumpulan Puisi Esai. Budaya Indonesia.

Hasneli. (2016). Pencegahan Dekadensi Moral: Pembinaan Kesehatan Mental Terhadap Eks Wanita Tunasuila. Jurnal Al-Qalb, 8, 15-24.

Huberman, A. M. \& M. B. M. (1992). Analisis Data Kualitatif. UI Press.

Kartini, M., Usman, J., \& Malik, I. (2016). Program Pengelolaan dan Pembinaan Eks-Wanita Tuna Susila ( WTS ) Pada Pusat Pelayanan Sosial Karya Wanita ( PPSKW ) Mattiro Deceng Kota Makasar merajalelanya Wanita Tuna Susila ( WTS ) atau sering disebut Pekerja. Kolaborasi : Jurnal Administrasi Publik, 2 no.1(April), 48-62.

Kholifah, S. (2019). Upaya peningkatan kesadaran diri melalui terapi dzikir jama'i. Spiritualita, 3(2), 239-259.

Koentjoro. (2004). On the spot: tutur dari sarang pelacur. Tinta Kelompok Penerbit Qalam.

Kuswarno, E. (2009). Fenomenologi Konsepsi, Pedoman, dan Contoh Penelitian. Media Padjadjaran.

Listyawati. (2020). Efektivitas Bantuan Sosial Bagi Eks Wanita Tuna Susila di Kabupaten Tulungagung Provinsi Jawa Timur. Media Informasi Kesjahteraan Sosial, 44 no.2, 165-189.

Moleong, L. (2000). Metode Penelitian Kualitatif. Remaja Rosda Karya.
Pambudi Putra Yahya, K. dan Z. B. H. (2018). Tinjauan Kriminologis Terhadap Kegiatan Praktik Prostitusi di Kota Makassar. Equilibrium: Jurnal Pendidikan Sosiologi, VI(1), 104-111.

Rakhmat, J. (2011). Psikologi Komunikasi. Remaja Rosdakarya.

Ramadhani, W. S., Sulastri, S., \& Nurhaqim, S. A. (2017). Proses Rehabilitasi Sosial Wanita Tuna Susila Di Balai Rehabilitasi Sosial Karya Wanita (Brskw) Palimanan Kabupaten Cirebon. Prosiding Penelitian Dan Pengabdian Kepada Masyarakat, 4(2), 241-245. https://doi.org/10.24198/jppm.v4i2.14292

Ramadhani, W. S., Sulastri, S., \& Nurhaqim, S. A. (2017). Proses Rehabilitasi Sosial Wanita Tuna Susila Di Balai Rehabilitasi Sosial Karya Wanita (Brskw) Palimanan Kabupaten Cirebon. Prosiding Penelitian Dan Pengabdian Kepada Masyarakat, 4(2), 241-245. https://doi.org/10.24198/jppm.v4i2.14292

Rohim, S. (2010). Konsep Diri Eks Wanita Tuna Susila Di Panti Sosial. Jurnal Ilmu Komunikasi UPNYK, 8(1), 103566.

Rohim, Syaiful. (2015). Self-Conception of The Vagrants in Jakarta. Komunitas: International Journal Of Indonesian Society And Culture, 7(1), 52-57. https://doi.org/10.15294/ komunitas.v7i1.3595 